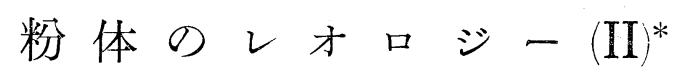

種 谷 真 一** 曽 根 敏 麿**

\title{
Rheology of Powder (II)
}

by

\author{
Shinichi TANEyA and Toshimaro Sone \\ (Research Laboratory, Snow Brand Milk Products Co., Ltd., Kita-ku, Tokyo)
}

In the previous paper we reported that the internal friction of powder is related to the variation of void during tapping or the powder constant of Nutting's equation. And it was seen that the shearing stress increases pulsatively with the increase of shearing displacement and saturates gradually.

In this study we carried out determination of pulsative vibration of the shearing stress during flowing of powder by the use of modified Green's rotational cylindrical viscometer. The stress of inner cylinder in response to the shearing stress of powder due to the rotation of outer cylinder represented pulsative vibration at early period and got to the constant of amplitude at the later period of rotating time.

From the results of the recording of pulsative flow patterns obtained employing various kinds of powder, it was found that the amplitude of vibration is related inverse proportionally to the cohesive property of powder.

From the analysis of flow pattern could be derived two types of mechanism of flow properties, i.e. the random flowing of each particles and the flowing of the block of powder. Both types of flowing of particles are attributed to the variation of void during flowing.

An empirical dependence of the mean torque on the duration of the experiment can be satisfactorily represented by the relation;

$$
\left|\left(T-T_{\infty}\right) /\left(T_{\infty}-T_{0}\right)\right|=\exp K N
$$

where $T$ is the mean torque at any time, $T_{0}$ the torque at the initial time of the experiment and $T_{\infty}$ the equilibrium torque after long time. $N$ is the number of rotation and $K$ is a constant relating to the speed of rotation and depending on the packing rate of powder. Subsequently the above equation agree to Roller's equation which was obtained from the relation between the variation of density of powder due to tapping and the number of tapping.

(Received Jan. 16, 1963)

\section{1.むえがき}

前報では粉体の圧縮および tapping 特性などの物理 定数と内部摩擦係数(角)の関係につき報告した。内部 摩擦係数は一面せん断法で測定し, せん断箱のずりの 增加につれてせん断抵抗は振動模様をえがき, 振動の 振幅は最初小さく，しだいに增加し漸次また減少する 傾向を示した.この機構は粉体の空間率の減少に伴う 粉体粒子相互の摩擦から, 粉体の流動には運動しうる 、最小の空間率が必要であるとして考察した。この流動 模㥞の解析に今回は二重円筒粘度計を用いて行なった。 粉体に粘度計を利用した例としては，まず fluidized powder につき，空気流速および粒子径に対するトル

* 原稿受付 昭和 38 年 1 月 16 日

** 雪印乳業( 株) 技術研究所
クの測定を行ない Newtonian flow の性質を示すと 結論した Matheson らの研究がある。この粘度計は stomer viscometer である。また最近 Benarie は乾 燥砂と油脂の薄膜をもつ砂につき Couette viscometer を用い付着力の測定を行ない理論的に解明してい る. 砂についてはその他小野らの実験があり、トルク は微振動し, トルクの值は必ずしも安息角に比例しな いと述い゙ている. 著者らは数種の付着性粉体および粒 体を用い，二重円筒粘度計でトルクの測定を行なった が, 粘度計は粉体の流動を研究する上に最も適してい ると思われる Green 粘度計を一部改良したもので， ここではトルクの時間的変化およびトルクの振動模様 と粉体の付着性との関係を報告する.

\section{2. 試} 料 
粉体としては比較的付着性のあるココア，市販砂糖， 全脂粉乳，でんぶん，流動性の上い脱脂粉乳，インス タント脱脂粉乳の 6 種類を用いた. Table 1 に各種粉 体の物理的性質を示す。

\section{3. 実験装置および方法}

実験装置の全景および内，外筒を Photo. 1 に示し た. Fig. 1 にはその略図を示したものである、シンク

Table 1 Physical properties of various powder

\begin{tabular}{l|r|c|c}
\hline Powder & $\begin{array}{c}\text { Mean } \\
\text { dia. }\end{array}$ & $\begin{array}{c}\text { Density at } \\
\text { loose } \\
\text { packing }\end{array}$ & $\begin{array}{c}\text { Cohesive } \\
\text { property }\end{array}$ \\
\hline Cocoa & $30 \mu$ & - & $122^{\circ}$ \\
Sugar & 400 & 0.660 & 157 \\
Whole rnilk powder & 60 & 0.589 & 104 \\
Starch & 55 & $0.8: 0$ & 97 \\
Skim milk powder & 50 & 0.689 & 63 \\
Instant S.M. powd ar & 300 & 0.284 & 75 \\
\hline
\end{tabular}
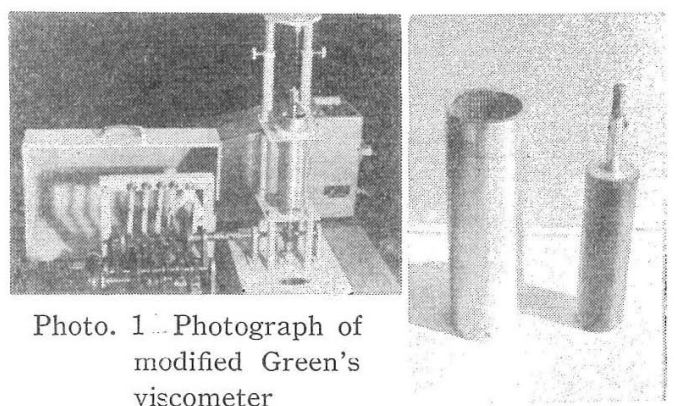

viscometer
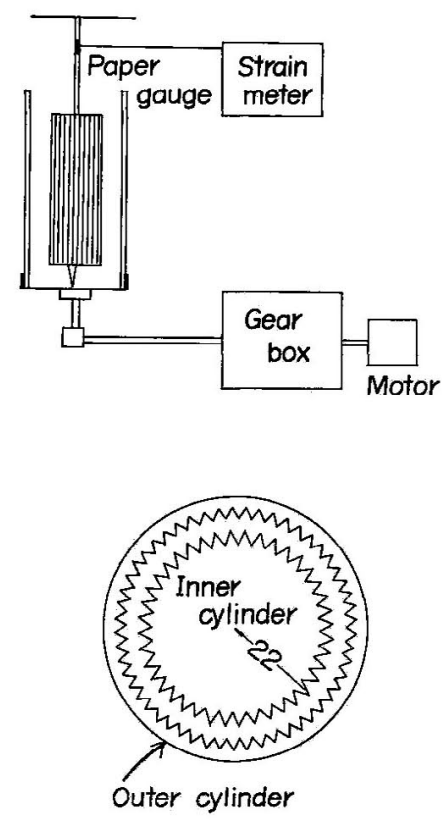

Fig. 1 Schematic diagram of modified Green's viscometer
ロナス・モーターに連動してある Gear boxにより， 外筒の回転数を 1，3，5，7，10 r.p.m. に变えられる. トルクの検出には 3.0〜3.6 mm $\phi$ のピアノ線を用い, その側面に $60 \Omega$ paper gauge 張り付け，2 gauge 法または 4 gauge 法で，ブリッヂ回路を作り出力増幅 により記録した。.内, 外筒は写真で明らかなように, 内筒側面および外筒内面に高さ $3 \mathrm{~mm}$ のきざみを入れ てある、このきざみは金属(真ちゅう製)と粉体の摩擦 抵抗を最大限にする目的のためで，このくぼみに粉体 は入れられ, 内筒と外筒間の同心円筒面でずりが起こ る.内䉍の有效直径(きざみの高さを入れる)は $44 \mathrm{~mm}$ で，外筒の有効直径は $54 \mathrm{~mm}$ である。すなわち内， 外筒間げきは $5 \mathrm{~mm}$ である. 粉体の場合, ずり速度こ う配はこの間げきで直線的でなく，非常に限られた面 にのみ生ずると考えられる，また，内筒の高さは 150 $\mathrm{mm}$ で，その上部 $20 \mathrm{~mm}$ まで粉体が詰宝る。粉体の 充てん法は緩密度充てんであり，内筒をピアノ線の付 いたまま(上部のピアノ楾の固定ねじかららはずす)外筒 とも取りはずし，粉体充てん後粉体にずりを与えない ように内，外筒居定する．固定後内筒 $5 \mathrm{~mm}$ 上部 に上げる. 各種粉体の充てん時の緩密度はTable 1 に 示したとおりである.

\section{4. 実験結果打よび考察}

\section{（I）流動模様と付着性}

内筒に作用するトルクは振動するのが普通である. 回転初期のトルクは粉体の充てんによる影響で备場所 で空間率が異なるため非常に大きな值を示す場合があ るが，ある時間経過するとほぼ一定の振幅となり漸次 振楅は小さくなる. Photo. 2 はほぼ一定の振幅にな っだとき，それぞれ gain を上げて流動模様を観察し たもので, いずれも $1 \mathrm{r} . \mathrm{p} . \mathrm{m}$. における流動を示す。 この 6 種類の粉体中砂糖, ココア, 全脂粉乳, でんぷ んは回転時間の経過とともにトルクは減少する。これ に反して脱脂粉乳，インスタント脱脂粉乳は増加する。 一般にトルクの増减は粉体の付着力に関俰があり，ま た振幅の高さもこれに影響するものである。回転数の 変化 (1〜10 r.p.m.) による流動模様はあまり変わらず,
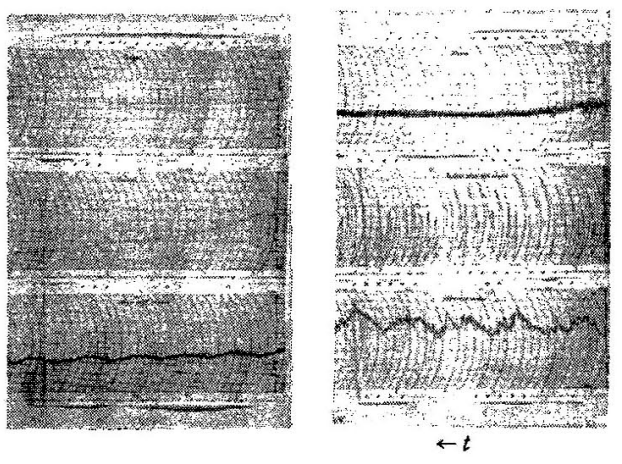

Photo. 2 Flow pattern of various powder 
一定の模様になる時間がずれるだけである。付着性の 測定には付着力の相対的值を示す流動性のよい粒体を 各種粉体に混合して，すべり角の測定を行なった。こ の実験では $0.5 \mathrm{~mm}$ のガラス球を乾燥し混合したもの で, Fig. 2 の横軸はガラス球の混合容積 $\left(v_{g}\right)$ に対する 各種粉体の混合容積 $(v)$ の割合で容積混合率で表わし ている，縦軸はその混合率における各種粉体のすべり 角である。すべり角 $90^{\circ}$ 以上の場合は実際には測定で きないが，直線的関係から各種粉体 $100 \%$ \%ける混 合率に外挿してすべり角を推定し，その粉体の付着性 を表わした。この結果を Table 1 にも示してある. さて，付着性と振幅の関係はどのような挙動を示すで あろう。Fig. 3 にこの関係を示した，振幅の高さは卜 ルク $(g-m)$ にて表示してある. 付着性の高いほど振幅 は小さく，流動性のよい粉体ほど振幅の高さは増加す る.この現象を流動模様から考察してみると, 砂糖, ココアはほぼ直線性であるに反し，でんぷんは小さな 微振動模様をえがき，全脂粉乳は微振動とともに大き

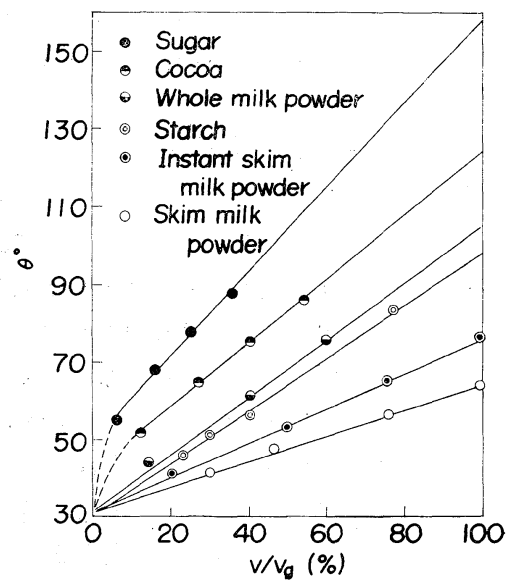

Fig. 2 Relation between sliding angle $(\theta)$ and volume mixing ratio $\left(v / v_{g}\right)$

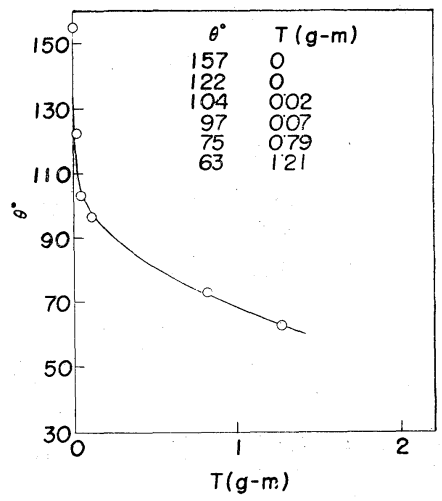

Fig. 3 Relation between sliding angle $(\theta)$ and torque $(T)$
な振動がありこの傾向は流動性のよい粉体ほど二つ の振動が顕著に現われる傾向を示す。インスタント脱 脂粉乳の場合には非常に複雑な様相を呈し，これは造 粒粒子のため粒度分布が広く，粒子径によって分離さ れる流動のためと考えられる，以上のように流動模様 の解析から二つの流動機構を観察でき, 粉体の流動は 粒子個々が流動する場合と粒子同土が付着力によりあ るかたまりになって流動する block 流動に大別され得 る. 砂糖,ココアは完全な block 流動であり,でんぷ んは小さなblockとして流動している. 全脂粉乳では 小さな block 流動のほかに粒子個々が多少流動する。 脱脂粉乳はblock 流動は非常に弱く，粒子の流動がか なり大きい要素を占めている。

\section{（II）回転時間経過によるトルクの全体的挙動}

回転初期の振動の平均トルク $T_{0}$, トルクの飽和する 值を $T_{\infty}$ ，任意の時間に対するトルクの值を $T$ とし， $\left(T-T_{\infty}\right) /\left(T_{\infty}-T_{0}\right)$ の值と時間の関係を Fig. 4 に示

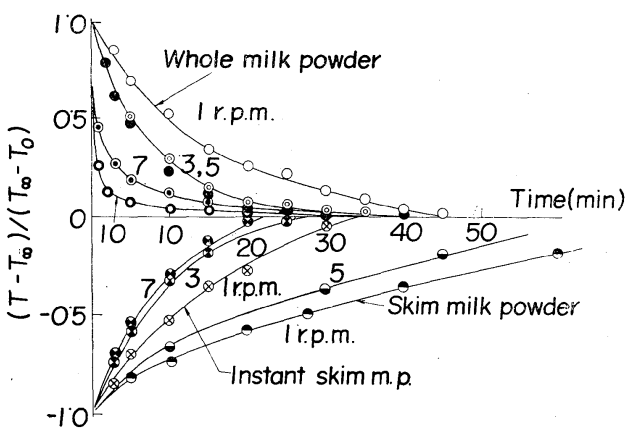

Fig. 4 Relation between $\left(T-T_{\infty}\right)\left(T_{\infty}-T_{0}\right)$ and time of rotation

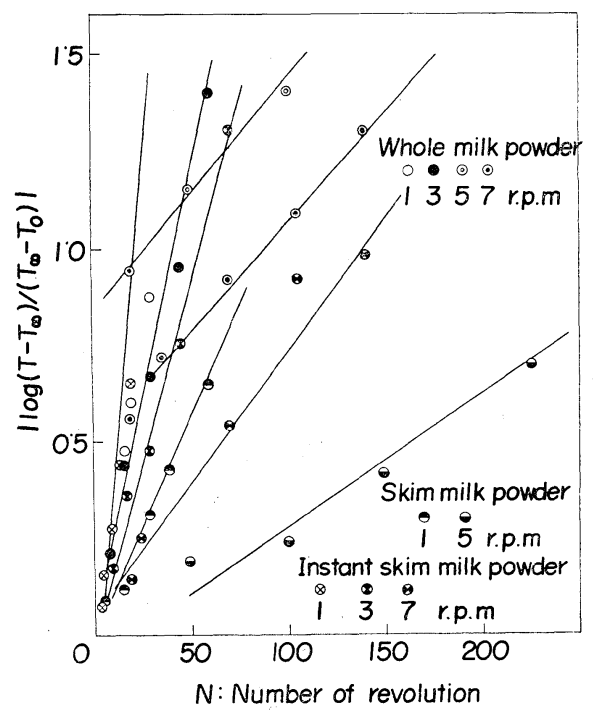

Fig. 5 Relation between $\mid \log \left(T-T_{\infty}\right) /\left(T_{\infty}\right.$ $\left.-T_{0}\right)$ and number of rotation $(N)$ 
した，縦軸の正に相当する曲線はblock 流動を行なう 全脂粉乳でトルクは隇少する，これに反して負に相当 する曲線は脱脂粉体およびインスタント脱脂粉乳を示 し，いずれもトルクの增加の傾向を示し，流動機構は おもに粒子個々の流動である．Fig. 4 の傾向を回転回 数 $(N)$ に対して $\left|\log \left(T-T_{\infty}\right) /\left(T_{\infty}-T_{0}\right)\right|$ の関係にて 表示すれば Fig. 5 のようになり, 直線的関係が得ら れる。すなうち( 1 式が成立する。

$$
\left|\left(T-T_{\infty}\right) /\left(T_{\infty}-T_{0}\right)\right|=\exp K N
$$

ただし，トルクは振動の平均值であり， $K$ は回転数に 依存する定数である。この式はまったく Rollerのガ ラス球を充てんし，衝撃落下して最密充てんにすると きの密度变化と落下回数の関係式 ( 2 式)に相当するも のである。

$$
\left(\rho_{f}-\rho_{n}\right) /\left(\rho_{f}-\rho_{0}\right)=\exp (-k n)
$$

$\rho_{f}, \rho_{0}, \rho_{n}$ 沬それぞれ最終見かけ密度, 最初の見か け密度, $n$ 回落下時の見かけ密度を表わしている。卜 ルクの測定はこの式から明らかなように, 粉体の密度 変化を示すもので, 回転による粉体のずりでの密度変 化も粉体を衝撃落下して詰める場合でも同じような挙 動を示すことになる。そしてトルクの振動は粉体が流 動しうる局所的空間率の変化を表わし, 砂糖, ココア のような微振動の現われない粉体は大きなかたまりが くずれ落ちる破壊現象として取り报うべきであろう。 この局所的空間率については Blown の実験があり, バンカーからガラス球を流動するとき, 流動口のわず か上部で 20〜40\%の空間率の変化を観察していて, この值からでも流動しやすい粒体は大きな局所的空間 率を示すものと考えられ，トルクの振動による振幅も

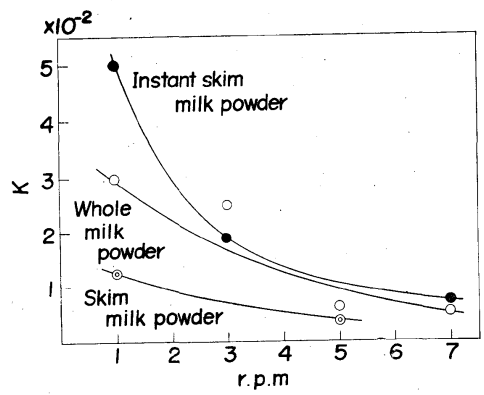

Fig. 6 Relation between $K$ and speed of rotation
增加するものといえる。(1)式のKの值は粉体が充て んされるときの充てん速度を意味する. Fig. 6 に $K$ と 回転数の関係を示したが, 明らかに回転数の増加につ れて減少する。すなわち, 粉体の充てん速度は速くな る傾向を示す，全脂粉乳の上うなトルクの減少を示す ものは相当ばらつきもあり, 回転数の增加につれて速 く block が形成されるものと考えられる.

\section{5 . 結}

\section{論}

粉体の流動に関し, Green 粘度計を一部改良し，内 筒に作用するトルクの振動を検出した。振動は普通回 転を与えてから, ある時間で活ぼ一定になり漸次小さ くなる。この振動模様は粉体の付着性と関係し, 付着 力の大きいほど振幅は小さく，流動幽のよい粉体は大 きくなる，振動模様の観察から粉体の流動に関し二つ の流動機構を見いだした。つまり粉体粒子個々による 流動と粒子同士の付着によって block を生じ，この block が流動に関与孛る機構である。粉体によっては この二つの性質をか将えた流動を起こす場合もある。 トルクのこのような振動は粉体の局所的空間率に基づ くもので，粉体が流動するに必要とされる空間率を間 接的に表わすものと考えられる.

回転最期のトルクの振動の平均值 $T_{0}$, 振動トルクの 飽和する平均值 $T_{\infty}$, 任意の回転時間における振動卜 ルクの平均值を $T$ とすれば次の関係式が成立する.

$$
\left|\left(T-T_{\infty}\right) /\left(T_{\infty}-T_{0}\right)\right|=\exp K N
$$

ただし， $N$ : 回転回数， $K$ は回転数に関係する定数 で, 粉体の充てん速度を意味する。この式は全く衝撃 による粉体の充てん方式の挙動と一致し，回転による ずりとしての充てんも衝撃による充てんも, 同一挙動 を示すように考えられる。

最後に本実験にご協力をいただいた千葉大米本雅男 君，投稿を許可していただいた当研究所長今村正男氏 に深く感謝いたします。

\section{参考 文 献}

1) 種谷, 兽根, 材料試験(レオロジー特集号), 11,104, 289 (1962)

2) 種谷, 曽根, 応用物理, 31-4, 286 (1962)

3) Matheson, Herbst and Holt, I.E.C., 41, 1099 (1949)

4) Benarie, British J. Applied Phys., 12-9, 514 (1961)

5）小野, 種谷, 粉体抢よび粉末治金, 投稿中

6) Roller, I.E.C., 22, 1206 (1930)

7) Blown, Nature, 191, 458 (1961) 